\title{
A Systemic Method for Organisational Stakeholder Identification and Analysis Using Soft Systems Methodology (SSM)
}

Wei Wang, Kent Business School, University of Kent, UK accwangwei@msn.com

Wenbin Liu, Kent Business School, University of Kent, UK w.b.liu@kent.ac.uk

John Mingers, Kent Business School, University of Kent, UK (corresponding author) 01227824008

j.mingers@kent.ac.uk

\begin{abstract}
This paper presents a systemic methodology for identifying and analysing the stakeholders of an organisation at many different levels. The methodology is based on soft systems methodology and is applicable to all types of organisation, both for profit and non-profit. The methodology begins with the top-level objectives of the organisation, developed through debate and discussion, and breaks these down into the key activities needed to achieve them. A range of stakeholders are identified for each key activity. At the end, the functions and relationships of all the stakeholder groups can clearly be seen. The methodology is illustrated with an actual case study in Hunan University.
\end{abstract}

Key Words: Stakeholder identification, stakeholder analysis, soft systems methodology

Published in the European Journal of Operational Research.

Online publication on $5^{\text {th }}$ May 2015

http://dx.doi.org/10.1016/j.ejor.2015.05.014 


\section{Introduction}

Organisations are complex systems that include many different groups within them, and affect many different groups and elements of their environment. These groups are generally referred to as the stakeholders of the organisation - those who have some "stake" in its activities. Some of these stakeholders are important for the successful operation of the organisation; some are important because of the effects that the organisation has on them. In both cases the organisation needs to be aware of these stakeholders and manage them successfully, the former for reasons of effectiveness, the latter for reasons of legitimacy and ethicality.

Much work has been done in the area of stakeholder theory in terms of determining different types of stakeholders (identification) and managing their interests and responsibilities (analysis). But much of this work takes a fairly ad hoc approach to identifying stakeholders in any particular real instance. Stakeholder identification is closely related to organisational strategic objectives and key activities. Organisations in different stages, with different objectives and key activities, will involve different stakeholders and they may change through time. Therefore "stakeholders" should be a dynamic concept. However, even if an organisation has determined its objectives, it is still not able to identify all stakeholder groups when the key activities of the organisation are not clearly defined. Until decisions about the primary products or services, customers, and modes of operation have been made, it is not possible to identify all the relevant stakeholder groups. This is the primary problem addressed in this paper - how to identify key stakeholders and how to decide on their relative importance.

In this paper we report on a systemic methodology that we have developed for formally identifying relevant stakeholders throughout the levels of the organisation and analyzing their relationship. The method is based on soft systems methodology (SSM). It begins with an agreed, top-level, objective and mission statement and then determines the activities needed to fulfill this. These key activities are broken down to whatever level of detail is considered necessary, and at each stage both wider and key stakeholders are identified. At the end of the procedure, all the stakeholders can be collected together, and their relationships and functions identified which helps with their management. The method is illustrated with a case study of the Foreign Languages School in Hunan University. 


\section{Stakeholder theory}

\subsection{The development of stakeholder theory}

Stakeholder theory was first developed (Freeman, 1984b) in the book "Strategic Management: A Stakeholder Approach", drawing on ideas from theories such as corporation social responsibility (Bowen, 1953; Jones, 1980), strategy management (Ansoff, 1965; Freeman \& Reed, 1983), and organisational theory (Salancik \& Pfeffer, 1978). Bowen (1953) argued that corporations should serve society and not just the interests of shareholders. Ansoff (1965) proposed that the objectives of corporations can be classified into two categories: economic objectives and social objectives, and that the achievement or outcomes of those social objectives will further enhance or limit the results of economic objectives. Organisational theorists from principal-agent theory (Jensen \& Meckling, 1976), institutional theory (Meyer \& Rowan, 1977), resource dependence theory (Pfeffer, 1981) and transaction cost theory (Williamson, 1975 ; 1985) examined the relationship between stakeholders and the organisation's internal or external environments.

From the beginning, stakeholder theory has been inter-related with many other theories, and there are many definitions of what constitutes a stakeholder. The classic definition of a stakeholder from Freeman (1984a, p.46) is: “. . any group or individual, who can affect or is affected by the achievement of organisation's objectives." It is one of the broadest definitions in the literature. Alkhafaji (1989, p.36) defines stakeholders as the "groups to whom the corporation is responsible"; Thompson, Wartick, \& Smith (1991, p.209) define stakeholders as "the group who has the relationship with the organisation", while Johnson \& Scholes (2002, p.190) suggest that "stakeholders are those individuals or groups who depend on the organisation to fulfill their own goals and on whom, in turn, the organisation depends". There is also a narrow view of stakeholder definition based on the language of the Stanford Research Institute (1963), defining stakeholders as "those groups without whose support the organisation would cease to exist" (Freeman \& Reed, 1983; Freeman, 1984a).

Frameworks have been produced to classify different forms of stakeholder theory. For example, Donaldson \& Preston (1995) classify the theory into three types: (i) descriptive theory that describes the actions which are taken by managers in order to deal with stakeholder relationship; (ii) instrumental theory that analyses and identifies the relationship between stakeholder management and the traditional objective (profits) of the firm; (iii) normative theory that suggests what managers should do in 
terms of business ethics and corporate social responsibility. The framework established by Donaldson and Preston divided stakeholder theory into research of the "facts" (empirical description and summary) and "value" (normative core). It addressed critiques that stakeholder theory could not be classified or identified, and it connected the two major goals or corporate objectives: business ethics and profitability.

Berman et al. (1999) take a convergent view of stakeholder theory. Any firm should consider stakeholder management from two sides: normative and instrumental. Effective stakeholder management is through establishing mutual trust and cooperation mechanisms as this allows companies to obtain a competitive advantage (Jones, 1995) and can also can help managers solve the conflicts between corporate earnings and business ethics (Freeman, 1999). They believe that regardless of the stakeholders' expectations, making profit is the common goal among the stakeholder groups. Therefore, the core principles of stakeholder management require not only a normative ethical standard, but also need to be conducive to achieving reasonable organisational goals.

In more recent literature, Freeman et al. (2010) discuss the development and applications of stakeholder theory in strategy, finance, marketing and other management disciplines. Harrison et al. (2010) justify stakeholder theory in economic terms, in order to gain wide acceptance in the strategic management field. Wang, Ge and $\mathrm{Lu}$ (2012) review a range of approaches to stakeholder analysis.

\subsection{Stakeholder theory in $O R / M S$}

Stakeholder theory is of relevance to OR/MS particularly in areas that recognize a multiplicity of actors or objectives (Munda, 2004) such as multi-criteria decision analysis (MCDA), soft OR, and ethical approaches. MCDA recognizes a variety of objectives and thus, implicitly at least, different actors or stakeholders who might support these objectives. Kodikara et al. (2010) used the PROMETHEE outranking method for evaluating alternative operating rules for an urban water supply. They identified three hypothetical stakeholder groups - resource managers, water users and environmental interest groups. De Brucker et al. (2013) argue for the importance of considering multiple stakeholder groups in using MCDA to try to resolve dilemmas in decision making within a sustainable development context. For example, trying to balance the interests of users, local authorities and manufacturers in a transport safety issue. Trutnevyte et al. (2012) discuss the importance of linking the visions of various stakeholders to their resource implications and practical feasibility, particularly in 
complex societal problems. In their example of identifying an energy strategy for a Swiss city, they engaged a group of eighteen people representing three main stakeholder groups. Interestingly for this paper, although all these examples stress the importance of stakeholders none have a specific method for identifying them.

Soft OR is also an approach that relies on identifying different stakeholder groups since it is premised on the idea that different actors in a situation (not necessarily identical to stakeholders) may have different views or perspectives about the problematic situation (Mingers \& Rosenhead, 2004; Mingers, 2011b). Ackerman (2012) points out that SSM (Checkland \& Poulter, 2006) identifies different actors through the CATWOE mnemonic (this will be developed later in the paper). SODA (Eden \& Ackermann, 1998) entails consideration of different roles such as client, sponsor, participants, winners and losers. And Strategic Choice (SCA) encourages the consideration of different stakeholders within public planning contexts. Ackermann and Eden (2011) give examples of the practical use of several tools including power-interest grids and stakeholder influence networks. Hermans \& Thissen (2009) are also concerned with public policy and survey a range of eighteen soft OR methods for actor analysis although, again, they do not include methods for identifying the actors in initially. Finally, Mingers (2011a) in discussing ethics, and particularly discourse ethics, argued for the importance of involving as many as possible of those who are affected by a proposal into an appropriate debate about it, and suggested that soft OR methods could play an important role in facilitating such a process.

\subsection{Stakeholder identification}

In practice, managers are the main body for identifying and responding to the interest of stakeholders. Managers tend to identify stakeholders from a business operations and profitability perspective (this view is in line with the instrumental theory) although moral or corporate social responsibility has been emphasized by most researchers (normative ethical theory) in terms of aspects such as gender equality, equity, sustainability and justice. We believe that stakeholder identification must consider both of these aspects. To some extent, an organisation tends to consider the stakeholders from an "instrumental view", to concern those stakeholders who have power or directly affect the business operations, such as shareholders. However, a single instrumental perspective may result in ignoring some stakeholder groups which have relatively less power or do not directly affect the operations, for example nearby residents of a chemical plant. Thus, the organisation not only needs to achieve its strategic objectives through a series of key activities which are including management 
and even some supporting activities, but also needs to consider their roles in moral and social responsibilities.

\section{The Broad View}

With the development and application of stakeholder theory, there are many different stakeholder identification methods for different organisational management scenarios. For example, based on the broad definition Clarkson $(1994$, p.5) proposes a risk-based model of stakeholders, and he classifies the stakeholders into two groups: (1) voluntary stakeholders: "are those individuals or groups who have knowingly or voluntarily made, or taken, stakes in a firm and thereby have assumed some form of risk." The voluntary stakeholders groups include: investors, employees, suppliers and so on; (2) involuntary stakeholders are: "those that are, or have been, unknowingly placed at risk as a result of the form's activities, goods or services". They may include local communities, the natural environment and so on. Therefore, Clarkson (1994) defines stakeholders as individuals or groups who have placed something at risk in relationship with the firm. Compared with the broad definition, the voluntary stakeholders can be seen as the stakeholders "who can affect the organisation", and the involuntary stakeholders are the groups "that are affected by the organisation". As Hill \& Jones (1992, p. 133) conclude, stakeholders are "constituents who have a legitimate claim on the firm...established through the existence of an exchange relationship".

Bryson (2004) presents fifteen different techniques for the identification and analysis of stakeholders. These are grouped into four categories: organizing participation; creating ideas for strategic interventions; building a winning coalition; and implementing strategic proposals. Between them, they go beyond just the identification of stakeholders all the way through the strategy-making process. Of particular interest is the "power-interest grid" which is a means of mapping potential stakeholders on a two-dimensional grid (Eden and Ackermann, 1998). This results in four categories - "players" who are high in both interest and power; "subjects" who are high on interest but lack power; "context setters" who have power but relatively little interest; and the "crowd" who are low on both.

A similar approach to the identification of important actors (as opposed to stakeholders) has been proposed by Enserink et al (2010) based on original ideas from Mitroff (1983). Whilst these methods are practically useful in getting a range of people involved, they are not directly linked to the strategy or activities of the organisation which is what our method does. 
Other identification methods based on the broad definition include, internal/external (Jones, 1995), fiduciary/non-fiduciary stakeholders (Goodpaster, 1991), necessary/contingent and compatible/incompatible (Friedman \& Miles, 2002). More recently, Crane \& Ruebottom, (2011) propose a model for stakeholder identification based on social identity. They claim that stakeholder groups are both socially and economically defined and their model is a cross-mapping of economic roles and social identities.

\section{The Narrow View}

Narrow identification methods extended the definition proposed by the Stanford Research Institute (1963). For example, Bowie (1988, p.112) proposes stakeholders should be individuals or groups "without whose support the organisation would cease to exist." Näsi (1995, p.19) also defines the stakeholders as some individuals or groups who "interact with the firm and thus make its operation possible". Clarkson (1995) classifies stakeholders into two categories: 1) primary stakeholder groups are ones without whose continuing participation the corporation cannot survive as a going concern; and 2) secondary stakeholder groups are defined as those who influence or affect, or are influenced or affected by, the corporation but are not engaged in transactions with the corporation and are not essential for its survival. Primary stakeholder groups typically are comprised of shareholders and investors, employees, customers, and suppliers, together with what is defined as the public stakeholder group: the governments and communities that provide infrastructures and markets. Clarkson (1995) asserts that if any primary stakeholder group, such as customers or suppliers, becomes dissatisfied and withdraws from the corporate system, in whole or in part, the corporation will be seriously damaged or unable to continue as a going concern. Indeed, the idea of "primary stakeholder" is almost coincident with the narrow definition proposed by the Stanford Research Institute and represents the narrow views of stakeholder theory.

Mitchell et al. (1997) developed a model that advances the idea that stakeholders can be classified into different groups in terms of three attributes-power, legitimacy, and urgency. (1) Power: the stakeholders who have the power or ability to influence organisational behavior. (2) Legitimacy: determines whether the claim a stakeholder has is desirable, proper, or appropriate with social norms, values, and beliefs (Suchman, 1995). (3) Urgency: The degree to which stakeholder claims call for immediate attention from managers. Mitchell et al (1997) then examined three types of stakeholders: (1) "Latent stakeholder", which are stakeholders who only have one attribute. These stakeholders often find it hard to gain enough attention from 
managers. (2) "Expectant stakeholders" who have two of the attributes, and they are likely to gain more attention and salience from managers. (3) "Definitive Stakeholders" who have all three attribute sand are therefore highly salient stakeholders in the organisation. The model proposed by Mitchell (1997) discussed how to give different degrees of salience or priority to the different stakeholder groups from a macro level perspective. However, it is less concerned with the micro levels - how to identify and respond to the stakeholders in terms of specific strategic objectives and key activities.

Some researchers have investigated the relationship between stakeholder theory and organisational objectives and behavior from a business management application perspective. Ehreth (1987) suggests that organisational effectiveness is not only achieving the objectives effectively, but also building relationships with stakeholders within the particular organisational environments. In other words, balancing the interests among stakeholders and stakeholders relationships are closely related to the processes of achieving the organisational objectives (that is key activities). Therefore, to achieve the organisational objectives, we need to consider stakeholders from two aspects: the normative core and the relationship between the organisation and its environments.

There is an increasing emphasis on considering the board view of stakeholders from the point view of business ethics and corporate social responsibility (Mingers, 2011a), rather than just in terms of profit or operations. Thus, we believe that a stakeholder identification method should take both broad and narrow definitions into account. The stakeholders will be identified into two categories: key stakeholders and wider stakeholders. We define the organisation's key stakeholders are "those individual or groups who are essential for the achievement of organisational objectives and key activities". Without these key stakeholders or their continued support, the organisational objectives or part of them will be difficult to achieve. And we also accept the broad definition of stakeholders as those individuals who are involved in, or affected by (directly or indirectly), the activities of the organisation (Ulrich, 1983; Vos, 2003).

Most of the existing identification methods only consider stakeholders from one perspective - macro level (broad view) or micro level (narrow view) - and they are often too instrumentally oriented or too broad to make the in-depth analysis of the relationship between key stakeholders and organisational key activity systems. In our approach we have developed a method based on Soft Systems Methodology (SSM) which allows us to both identify the top level strategic direction of the organisation as 
well as decomposing that down into key activities at a more detailed level. The approach is derived from the $3 \mathrm{E}$ methodology (which is based on SSM) for defining key performance indicators (Liu et al., 2012; Mingers et al., 2009).

\section{Stakeholder identification based on SSM}

\subsection{SSM and stakeholder theory}

The recognition of a variety of stakeholders can be seen to stem from a systems perspective. Churchman $(1968 ; 1971)$ emphasized the idea that in designing systems one needs to "sweep in" all those who are affected by the design, not just those who are directly involved. The reason for this being that any one viewpoint or perspective is inevitably limited and so for a good or robust design we should try to synthesize as many viewpoints as possible. Freeman (1984a), in his original stakeholder theory, saw it as the "stakeholders in a system". Equally, Ackoff (1974) argued that to deal with system problems (especially soft systems problems involving human activities), all stakeholders should become participants. His view was that even when there were apparent conflicts between different stakeholder groups, it should be possible with open debate and discussion, to design a system that could be acceptable to all. $\mathrm{He}$ encapsulated this in the maxim "design an ideal future and then bring it about". Thus, achieving the organisation's strategic objectives or to improving the organisation's performance can be seen as a system problem, and it can only be solved by redesigning the key activities systems though discussion and debate among the key stakeholders and thereby balancing their interests.

There has already been some work done on combining stakeholder analysis with systemic approaches. Simmons (2003) and Simmons et al. (2005) consider combining stakeholder analysis with SSM in the design of organisational systems and Vidgen (1997) used some SSM concepts in a stakeholder analysis of information systems for aircraft design. Pouloudi (1999) is concerned with the stakeholder concept in developing information systems and considers links to SSM, actor network theory (ANT) and inter-organisation systems. Pouloudi \& Whitley (1997) explore a method for the identification of stakeholders in information systems and suggest four principles based both on the literature and case studies in the management of drug use. i) Stakeholders depend on the specific context and time frame - it is not possible to develop generic maps of stakeholders regardless of context. ii) Stakeholders cannot be viewed in isolation from each other; they have to be seen as a complex network of interactions, interests and power potentials. iii) The positions of stakeholders are dynamic - they may change over time. iv) Stakeholders cannot always achieve all that they might want. Finally, Vos (2003) examines critical systems heuristics (CSH) as a 
way of challenging narrowly drawn systems boundaries that might exclude some of the "affected" as well as the "involved".

Soft systems methodology (SSM) was first introduced by Checkland in 1972 (Checkland, 1972). The soft systems idea was developed from biology and engineering, originally to deal with "hard" problems (with clearly defined goals in essentially a design role). But traditional "hard" systems analysis has failed considerably in its attempt to deal with "soft" problems (Freeman \& Reed, 1983). Stakeholder management and stakeholder identification involve many "soft factors", such as human activities, conflicts, emotions and so on. SSM was based on the "open-world assumption": not simply accepting the existing situation, but entering and understanding the complex problem and expressing it in a structured way (through a rich picture, root definitions and conceptual models). SSM draws a strong distinction between the real-world problematic situation and the conceptual world of systems thinking. A variety of particular constructs are used in the conceptual world and then compared with the complex and messy real-world in order to develop learning for change. The approach that we will take is developed from the $3 \mathrm{E}$ methodology for performance management, which is based on SSM and has been used in a variety of organisations (Liu et al., 2012).

The primary constructs of SSM are:

Root definitions (RD) which are succinct descriptions of notional systems of human activity. They are brief sentences that usually begin: "A system to .....". These can be structured using other constructs, for example:

CATWOE, which stands for Customer (those people who are the recipients of the systems output; Actor (the people who perform the activities of the system); Transformation (the change that the system brings about); Weltanschauung (worldview - the viewpoint that justifies the activities of the system); Owner (the person or system who can create, change or destroy the system) and Environment (external systems or constraints that must be taken as given).

$P Q R$, what does the system do? How does it do it? Why does it do it? This suggests that an RD can be written as: "A system to do P by Q in order to R".

Conceptual models (CM) which model the activities that the root definition must necessarily undertake and their relationships.

The 3Es are measures of performance of the system.

E1, Efficacy - does the system produce the output it is supposed to?

10 
E2, Efficiency - does the system use a minimum of resources?

E3, Effectiveness - does the system meet the goals and aspirations of the owner?

The process of SSM is illustrated in Figures 1 and 2. The real-world situation is examined and expressed, often in a "rich picture". Then a variety of RD/CM pairs are developed from different perspectives. These models are then compared with the appreciation of the actual situation generated in the first stage and the differences then form the subjects for debate about desirable and feasible changes. The whole process should be participative and should encourage discussion and debate.

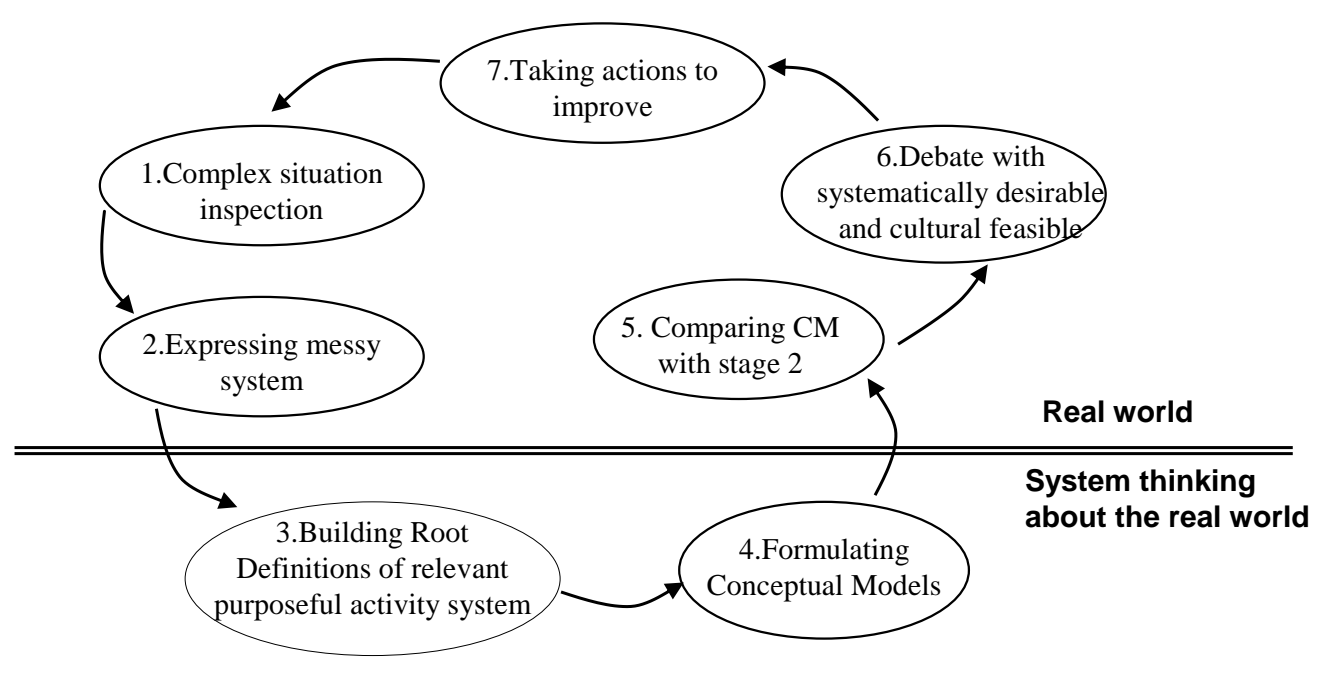

Figure 1: Seven steps of SSM 


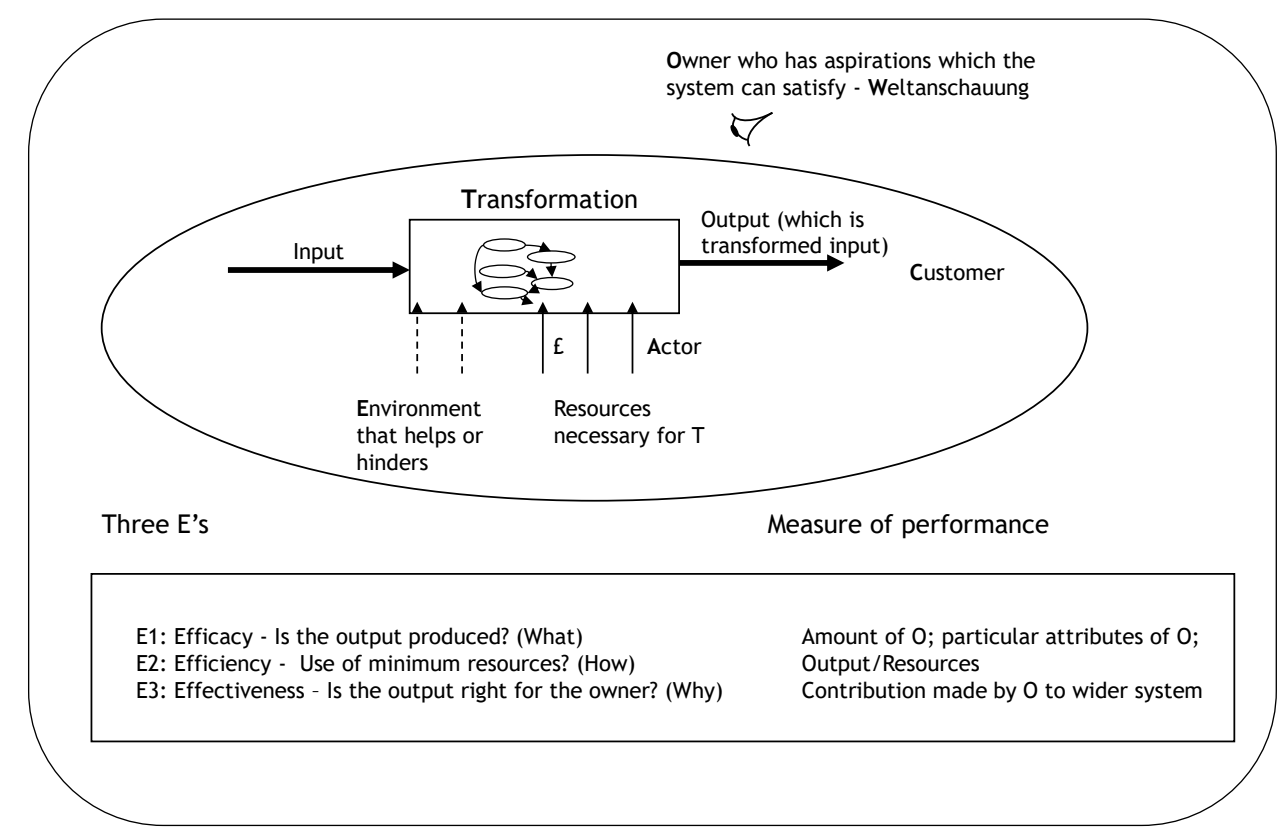

Figure 2: Representation of the CATWOE analysis and the 3E's from SSM

Note that in Figure 2, as well as the six elements of CATWOE we have added in another one - the Resources necessary to achieve the transformation. This also points to an extra category of potential stakeholder - the suppliers of the resources.

\subsection{Stakeholder identification method using SSM}

The method that we have developed, using the constructs and processes of SSM, will identify the key stakeholders and will have two further characteristics: (1) this method is able to represent the key activity sets which are essential to achieve organisational objectives; (2) it is able to help managers to determine the functions and roles of each key stakeholder group in the processes of achieving the organisational objectives.

From our experiences in practice, identifying stakeholders should be tied up with formulating and deconstructing the organisational strategic goals. Achieving the organisational strategic goal could be the initial objective for a firm, and then it (the objective) could be further broken down into sets of key activities, level by level continuously, in order to better control and manage the implementation of strategies. It is necessary to get a wider range of stakeholder groups involved into these 
processes in order to ensure their balanced interests are reflected in the organisational strategic objectives, and to avoid unnecessary conflicts and misunderstandings. Generally, looking at the organisational hierarchy from top to bottom, the relevant organisational objectives will change from a broader long-term strategic goal to the narrower short-term tactical and day-to-day operational objectives. The closer to the bottom level, the more the key activity set will become such operational activities. Usually, organisations need to consider all stakeholders' interests comprehensively, not only when they are deciding the organisation's top goals, but also at different hierarchical levels.

Organisations have to implement continuous monitoring, coordinating and motivating of each key stakeholder group through the implementation of different levels of organisational objectives in order to ensure that the overall objective can be achieved efficiently and effectively. Consequently, organisations should not only identify stakeholders from a top level. They also need to identify more precisely the key activities, sub-activities and relevant stakeholders from top to bottom. Through this top to bottom identification process, a broader stakeholder group will be subdivided, even down to individuals (e.g. an employee such as departmental secretary). There are individuals or groups who keep joining or leaving the stakeholder set based on changing objectives and key activities. Thus, through this process the stakeholders can be identified as precisely as possible, and this will be dynamic, representing their functions and roles under the different key activities. Finally, after all key activities, sub-activities and relevant stakeholders have been clearly identified. It is possible to determine the function list (explained below) of each stakeholder group by gathering the same type of stakeholder in different systems and sub-systems in the organisation.

If we define achieving an organisation's strategic goal as the initial objective, we then decompose the initial objective level by level by using SSM. For instance, the upper level objective A could first decompose into lower level key activities $B_{1}, B_{2}, B_{3}$. And then $\mathrm{B}_{1}$ could be the upper level objective for further decomposing into several more specific sub-activities $\mathrm{C}_{1}, \mathrm{C}_{2}$. Thus, the relationship between objectives is: the activity in a former decomposition could be the objective for further decomposing. Assume stakeholder $S^{1}$ is the stakeholder for achieving key activities $B_{1}$ and $C_{2}$. Then we believe that the function of $S^{1}$ through the process of achieving the overall objective $A$, is reflected by key activities $B_{1}$ and $C_{2}$, using set $\left\{B_{1} 、 C_{2}\right\}$ to represent the function list of $S^{1}$. After the functions for all stakeholders have been listed, then this provides a powerful basis for managers to determine the importance of each 
stakeholder group and it makes the stakeholder management more reliable, in this sense.

Thus we can now have a formal procedure to identify stakeholders. The core of this method is to continuously ask and answer the questions, what to do? why do it? and how should it be done?, following carefully structured and constructive procedures, as described in SSM. However, in practical applications it may be very expensive to implement any change in a business procedure, and one may have to just follow the existing business procedures and the given management framework. In that case, one does not need to answer the question why.

Based on CATWOE from SSM and the idea of the "involved" and the "affected" from critical systems heuristics, we have developed a framework of different categories of potential stakeholders (Table 1). We should note that all these categories are social roles. This means that in any particular analysis it will be necessary to determine which person or group(s) fill each role.

Table 1: Categories of stakeholders derived from CATWOE and CSH

\begin{tabular}{|c|c|c|c|c|c|}
\hline \multicolumn{4}{|c|}{ The Involved } & \multicolumn{2}{|c|}{ The Affected } \\
\hline $\begin{array}{l}\text { Owners who can } \\
\text { create, change or } \\
\text { destroy the } \\
\text { system and who } \\
\text { supply the } \\
\text { Weltanschauung }\end{array}$ & $\begin{array}{l}\text { Customers } \\
\text { who are the } \\
\text { direct } \\
\text { recipients of } \\
\text { the output of } \\
\text { the system. } \\
\text { They may be } \\
\text { seen as } \\
\text { beneficiaries } \\
\text { or victims }\end{array}$ & $\begin{array}{l}\text { Actors who } \\
\text { perform the } \\
\text { activities of } \\
\text { the system }\end{array}$ & $\begin{array}{l}\text { Environmental } \\
\text { groups who are } \\
\text { directly } \\
\text { necessary for the } \\
\text { system, e.g., } \\
\text { suppliers of } \\
\text { resources }\end{array}$ & $\begin{array}{l}\text { External } \\
\text { groups } \\
\text { indirectly } \\
\text { affected by } \\
\text { the systems } \\
\text { activities }\end{array}$ & $\begin{array}{l}\text { External } \\
\text { groups who } \\
\text { indirectly } \\
\text { affect the } \\
\text { systems } \\
\text { activities }\end{array}$ \\
\hline
\end{tabular}

The primary distinction is between the involved and the affected. The primary difference here is that the involved are those who would, in any case, be part of the system. Those without whom the system could not occur. That does not necessarily mean that they would automatically be seen as stakeholders, especially in the traditional narrow view. For example, many decisions are made in organisations without consulting, say, employees or even customers. But nevertheless, they are a 
direct part of the system. We should remember, at this point, that all these constructs are notional within SSM; they are not intended to be directly descriptive of reality. They also do not necessarily correspond with organisational boundaries. This is especially obvious with complex inter-organisational projects which may well involve several different organisations. Thus "being part of the system" is not synonymous with "being part of the organisation".

In contrast, the affected are those who are clearly not part of the system, being in its environment, and yet are indirectly involved in the activity, either being affected by it, or affecting it in some way. Obvious examples are local communities, the natural environment, the local economy (shops, taxis, petrol stations etc.).

As with all systems analysis, these various boundaries are not just given but very much matters of judgment (Midgley, 2000). Take, for example, suppliers of resources (which may be non-physical, e.g., expertise or information). In some situations, where there is a strong and necessary supply chain or perhaps only one or two suitable suppliers, they might be taken as involved; whereas in others where there are many potential suppliers of a common resource, they may just be seen as affected but not involved. The other point to make, especially with the affected groups, is that it may not be possible to include them directly, for reasons of cost or practicality it may only be possible to include representatives, e.g., representatives (or witnesses as CSH would call them) of the local community, or of common resources.

Given these categories, the method begins at the top level, as defined for the particular project, and decomposes activities to lower levels, identifying the stakeholders in each level. We summarize the proposed procedures in the following five steps:

1. Determine the overall objectives of the organisation (or part of it). Understand and structure the mission, objectives, and complex environmental and internal factors of the organisation. Determine the organisation's existing managerial hierarchy structure and build the "root definition" for achieving the initial strategic objectives. This may need a process of discussion and debate among a variety of initial stakeholders to reach a consensus or accommodation.

2. Search for "initial stakeholders", that is the group of stakeholders who will be part of the initial discussions about the mission, strategy and so on. The initial stakeholders contain two categories: the wider stakeholders and the key initial stakeholders. Firstly, we identify initial wider stakeholders 
through the set of categories in Table 1 . We cannot practically expect that all these groups will be involved in the analysis so we then have to narrow this down to the initial key stakeholders by using the narrow definition, "those individuals or groups who are essential for the achievement of organisational objectives and key activities". There is then a process of discussion and debate among these key stakeholders to reach a consensus or accommodation about an organisation's strategic objectives, key activities as well as their world views (Weltanschauung). It is essential to develop the consensus or agreement among the initial stakeholders in order to ensure the objectives and conceptual models (CMs) are systemically desirable and culturally feasible.

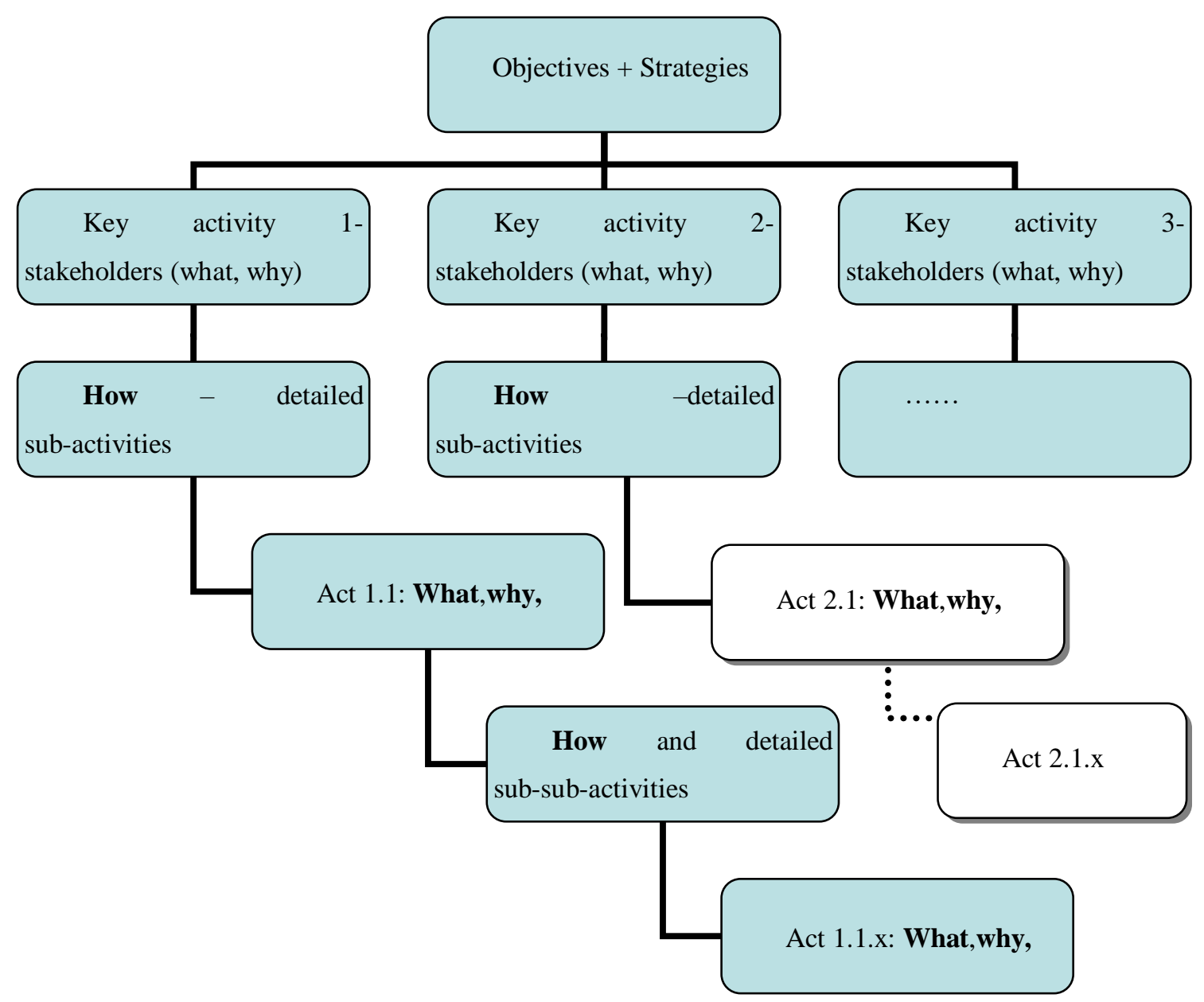

Figure 3: Decomposed Activities 
3. Build root definitions and conceptual models. Based on SSM, transfer the root definition into a set of purposeful key activities. The initial strategic objective is then broken down into a set of key activities or actions which together should logically or actually ensure that the overall objective is achieved (the how). They may or may not be the same as the current practices in the organisation. Consensus needs to be reached among the relevant initial stakeholders for any changes. Also, the inter-connections between key activities should be considered.

4. Continually decompose the activities. It is often the case that the key activity needs to be further broken down. When this happens, steps 2) and 3) should be repeated for any key sub-activity for which this is felt necessary. Then 4) is repeated recursively until all necessary key activities are clearly seen. Therefore, we are able to identify the key stakeholders for those clearly defined key sub-activities in each level from the bottom to top (see Figure $3)$.

5. A complete set of stakeholders can then be produced from the key activity models bottom to top and level by level. Through the process of inducting and summarizing the stakeholders, the set could clearly represent the functions of the stakeholders at each level of key activities in the process of achieving the organisational strategy goal. For an example see Table 5.

\subsection{Comparison with other methods}

Instead of being carried out as a separate activity, in real-world applications stakeholder identification and analysis are often embedded into processes of strategic planning or deploying as described for example by Bryson (2004), or as a part of strategic performance management exercise (Liu, et al 2012). In this regard, our method differs from these well-known approaches in that our method utilizes a comprehensive system approach. In the literature, links between a systems approach (here SSM) and stakeholder identification and analysis have been explored by Enserink et al. (2010) where a multi-actor system diagram is used to identify the actors. The process consists of three parts: i) perform the actor-network analysis to identify the critical actors; ii) explore what factors may be influenced by other actors; and iii) explore how use of the means of the problem owner may affect other actors' interests. Another example is Eden and Ackermann (2011) where a stakeholder-influence network (or web) was built by using some stakeholder analysis tools like power-interest grid analysis, acknowledging multiple and interdependent 
interactions among stakeholders - one stakeholder's actions can generate a dynamic of responses across a range of other stakeholders. They also point out the importance of linking strategy and top management, and of disaggregating the stakeholders for management, which have been dealt with in our approaches in a more systemic way.

In comparison with the methods mentioned in the literature, our approach, by utilizing the SSM, is able to carry out in-depth analysis through the whole processes of strategy intervention, decomposition and deployment at different levels, related to organisational strategies and the key supporting activities (Liu, et al, 2012). We explicitly link stakeholder identification and analysis with strategy and top management by starting to identify stakeholders from the top level of an organisation according to its objectives and strategies. Also our approach can conveniently disaggregate the identified stakeholders according to the management hierarchy of the organisation for management.

On the other hand, our method differs from standard SSM in the following three main ways:

i) It is closely linked with strategies and deployment of an organisation, in our method "how-to-do" has to consider the higher level strategies. Thus the logic modelling parts of SSM may not be used all the time when, for example, it is clear how the strategies should be implemented due to cost or technical restrictions. Furthermore our method not only identifies various stakeholders but also the roles of stakeholders. All stakeholders played certain roles in the implementation of the strategies, and they can be clearly identified through listing or categorizing all the decomposed key activities which are involved in or affected by each stakeholder group.

ii) It is closely linked with wider stakeholders and thus implicitly with their interests. When modelling the activities, wider stakeholders were invited to consider "how to do" and thus their interests before it is decided - this is very important in the public sector where residual profits cannot be effectively used to motivate the staff. However only those very relevant to management will be included into the final stakeholder groups after the final levels of how-to-do are decided. Our method then goes from the bottom to top to finalize the stakeholders to be included.

iii) It is closely linked with the management structure of an organisation. After completing the stage of deciding how-to-do - that is deployment of objectives and strategies as mentioned above - our method has to finalize and disaggregate the key stakeholders from the top to the bottom according to the management hierarchy so 
that the management can effectively manage different groups of stakeholders and balance their interests later.

\section{Case study: the Foreign Language School of Hunan University ${ }^{1}$}

Scientific research, as one of the three main functions for higher institutions, is increasingly recognized in China. Nowadays, more emphasis is placed on scientific research rankings which, to some extent, can influence the funding and position of a university. Academic schools are the basic units of a university. Thus, it is vital to study how to evaluate and manage the scientific research level and scientific research achievements of these schools in order to invest the limited resources in those with potential.

Hunan University has a long history but it is currently only a middle-ranking university in China. The University is determined to regain is previous high position. The strategic target of Hunan University is to build up a distinctive and comprehensive university which reaches national top research levels and moves towards being an international high-ranking university. This aim should be combined with the three main duties of higher education: training talent, scientific research and social service. According to the strategic plan of the University, the main development objectives of the subordinated schools (including the Foreign Language School) could be formed by breaking down the strategic goals from the university level. Here, as an example, we discuss how to develop scientific research management procedures and performance indicators for the School of Foreign Languages.

The School is in the process of setting up a management system for its scientific research. The first step of this process is to develop management procedures and the corresponding indicator system for performance evaluation. Based on our experience, the following methodology was proposed. A working group was formed with the School Party Leader (in university schools it is normally the Party Secretary who is in charge of management procedures), the Vice-Director who was in charge of research, one secretary, one interpreter and the authors.

Step One: Top level analysis. Although the project aims to identify key stakeholders for the scientific research of the School, the School is obliged to serve the top level purpose---the goal of the University as a whole (E3). In theory, the goal of a university should be seen from the university mission statement or the related

\footnotetext{
${ }^{1}$ Note that the research was actually carried out in Chinese - it has been translated into English for this paper. 
documents, and it should be confirmed and be described in the "what to do-how to do-why to do" format. However, this turned out to be a messy and difficult job since so much was stated in the mission statement of the University. The Party Leader had to discuss with several relevant people (wider stakeholders) to clarify the University's primary goal. In the end, it was agreed that the development goal of the University is "to build up a distinctive and comprehensive University which reaches national top research levels and marches towards being an international high-ranking university". Then, a clear mission statement should be constructed in the form of what-how-why (essentially a root definition):

"Concentrate excellent research in certain selected fields: at least at national, some of them at international level (What); build strong research teams in these fields and produce research results that are in the first class in China or may be useful in language teaching (How); in order to have a first class foreign language School in China with clear characteristics, and some subjects internationally known (Why)".

Step Two: Based on the CATWOE analysis, the "initial wider stakeholders" for the objective (scientific research) have been identified, and are, namely: the University (Owner, Customer), the Foreign Language School (Actor), the Government (Resource, Environments), students (Actor and Customer), local residents (Environments), and a local publishing company (Resource). From the narrow definition, the key stakeholders are: University (Owner, Customer), Foreign Language School (Actor), Government (Resource, Environments) and students (Actor and Customer).

Step Three: Construct more detailed strategies for how to reach the objectives. For instance, one should develop strategies to "concentrate excellent research in certain selected fields, at least at national...". The procedures will first be proposed by the working group and then discussed with upper level stakeholders of the School. Thus it provides a chance for the School to rethink its development strategy and management procedure and to see whether a proper scientific operational mechanism can be established for supporting the realization of the goal. After several feed-back and discussion sessions, the following conceptual model (CM) (the detailed "how", 10 key activities) was agreed and introduced (see Figure 4). 


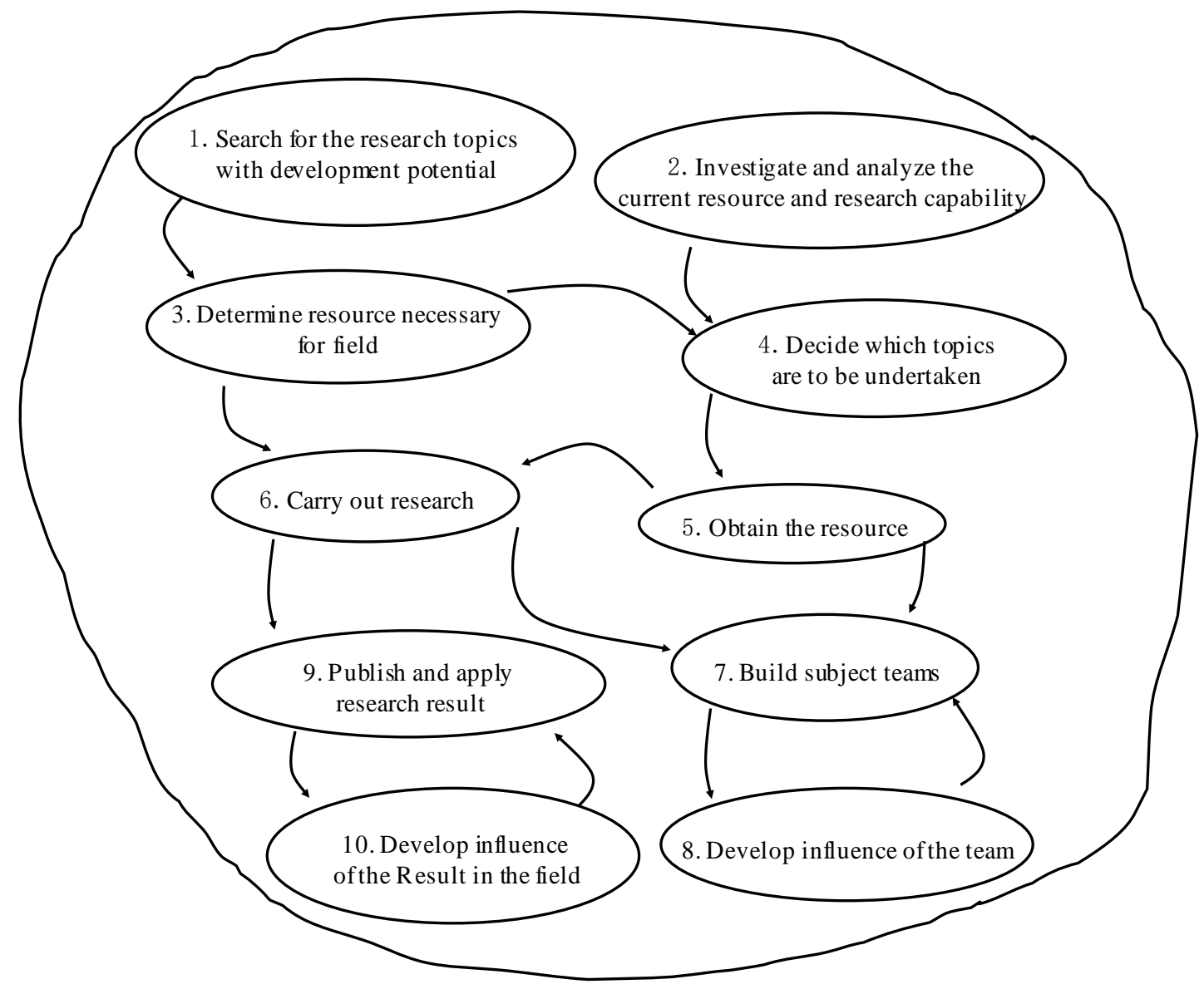

Figure 4: Agreed research activity top level model for the School of Foreign Languages.

At this stage, it is not clear how to achieve or deploy some of key activities in the above conceptual model - we need to further identify relevant "initial stakeholders" for these key activities. In practice, we could ask who are the Owner, Actors and Customers, Resources, and Environments (based on CATWOE analysis) for implementing those key activities, in order to help us to identify relevant wider stakeholders more comprehensively. Consensus, or at least agreement, needs to be reached among the initial stakeholders in order to create the sub-conceptual models. As we can see in Tables 2-4, in this case, most of the initial stakeholders are "involved" stakeholders (Owner, Actor, Customer) but some are more likely to be "affected" such as Government, local residents, external researchers and publishing company. We can then we can further identify whether or not they are the "key" by using the definition given above. 
Table 2: Key activities, upper level initial stakeholders and relevant initial stakeholders for objective "scientific research" (note that in Tables 2-4, O, C, A, R, E refer to CATWOER)

\begin{tabular}{|c|c|c|c|}
\hline $\begin{array}{l}\text { Upper level initial } \\
\text { stakeholders }\end{array}$ & \multicolumn{2}{|r|}{ Key activities } & Relevant initial stakeholders \\
\hline \multirow{10}{*}{$\begin{array}{l}\text { 1.University }(\mathrm{O} \text { and } \mathrm{C}) \text {, } \\
\text { 2.Foreign language } \\
\text { school (A) } \\
\text { 3.Government ( } \mathrm{R} \text { and } \\
\text { E) } \\
\text { 4.Student (A and C) } \\
\text { 5.Local residents (E) } \\
\text { 6.Local publishing } \\
\text { company (R) }\end{array}$} & 1 & $\begin{array}{l}\text { Search for the research topics with } \\
\text { development potential }\end{array}$ & $\begin{array}{l}\text { University }(\mathrm{O}), \text { School(A), Research } \\
\text { team }^{2} \text { (Actor, Customer)、 External } \\
\text { research stakeholder(A\&C) })^{2}\end{array}$ \\
\hline & 2 & $\begin{array}{l}\text { Investigate and analyze the } \\
\text { current resource and research } \\
\text { capability }\end{array}$ & $\begin{array}{l}\text { School (Owner), External research } \\
\text { stakeholder(Actor, Customer), }\end{array}$ \\
\hline & 3 & $\begin{array}{l}\text { Determine resource necessary for } \\
\text { field }\end{array}$ & $\begin{array}{l}\text { University, School(Owner), Teaching } \\
\text { staff (Actor), Student (Customer), }\end{array}$ \\
\hline & 4 & $\begin{array}{l}\text { Decide which topics are to be } \\
\text { undertaken }\end{array}$ & $\begin{array}{l}\text { School }(\mathrm{O}) \text {, Research team }(\mathrm{A} \& \mathrm{C}) \text {, } \\
\text { External research stakeholder(A\&C) }\end{array}$ \\
\hline & 5 & Obtain the resource & $\begin{array}{l}\text { University (upper system), School (O), } \\
\text { External research stakeholder (A\&C) }\end{array}$ \\
\hline & 6 & Carry out the research & $\begin{array}{l}\text { University, External research } \\
\text { stakeholder(A\&C), Research } \\
\text { team(A\&C), }\end{array}$ \\
\hline & 7 & Build subject teams & School (O), Research team (A\&C) \\
\hline & 8 & Develop influence of the team & $\begin{array}{l}\text { School }(\mathbf{O}) \text {, Research team, External } \\
\text { research stakeholder (A\&C) }\end{array}$ \\
\hline & 9 & Publish and apply research results & $\begin{array}{l}\text { University }(O), \text { Teaching staff }(A \& C) \text {, } \\
\text { Research team }(A \& C),\end{array}$ \\
\hline & 10 & $\begin{array}{l}\text { Develop influence of the result in } \\
\text { the field }\end{array}$ & $\begin{array}{l}\text { University }(O), \text { School(A\&C), Research } \\
\text { team(A\&C), External research } \\
\text { stakeholder (R\&E) }\end{array}$ \\
\hline
\end{tabular}

Step Four: Again at this stage, it is not clear how to achieve some activities. Thus, steps 2 and 3 were repeated for each of those activities in turn. For each activity we agreed a what-how-why statement and then a model of activities.

For ease of comparison, we use activity 1 from Figure 4 as an illustration. Here the what-how-why statement was agreed for activity 1, which was: "Search for research topics with development potential". In order to develop further activity

\footnotetext{
${ }^{2}$ Research team: including academic leader, research staff, students, etc.

${ }^{2}$ External research stakeholder: including external resources owner, external research partner, external research staff, etc.
} 
models for achieving this, we had to discuss many administrative details with the relevant initial key stakeholders.

1. Seek for the research topics with development potential

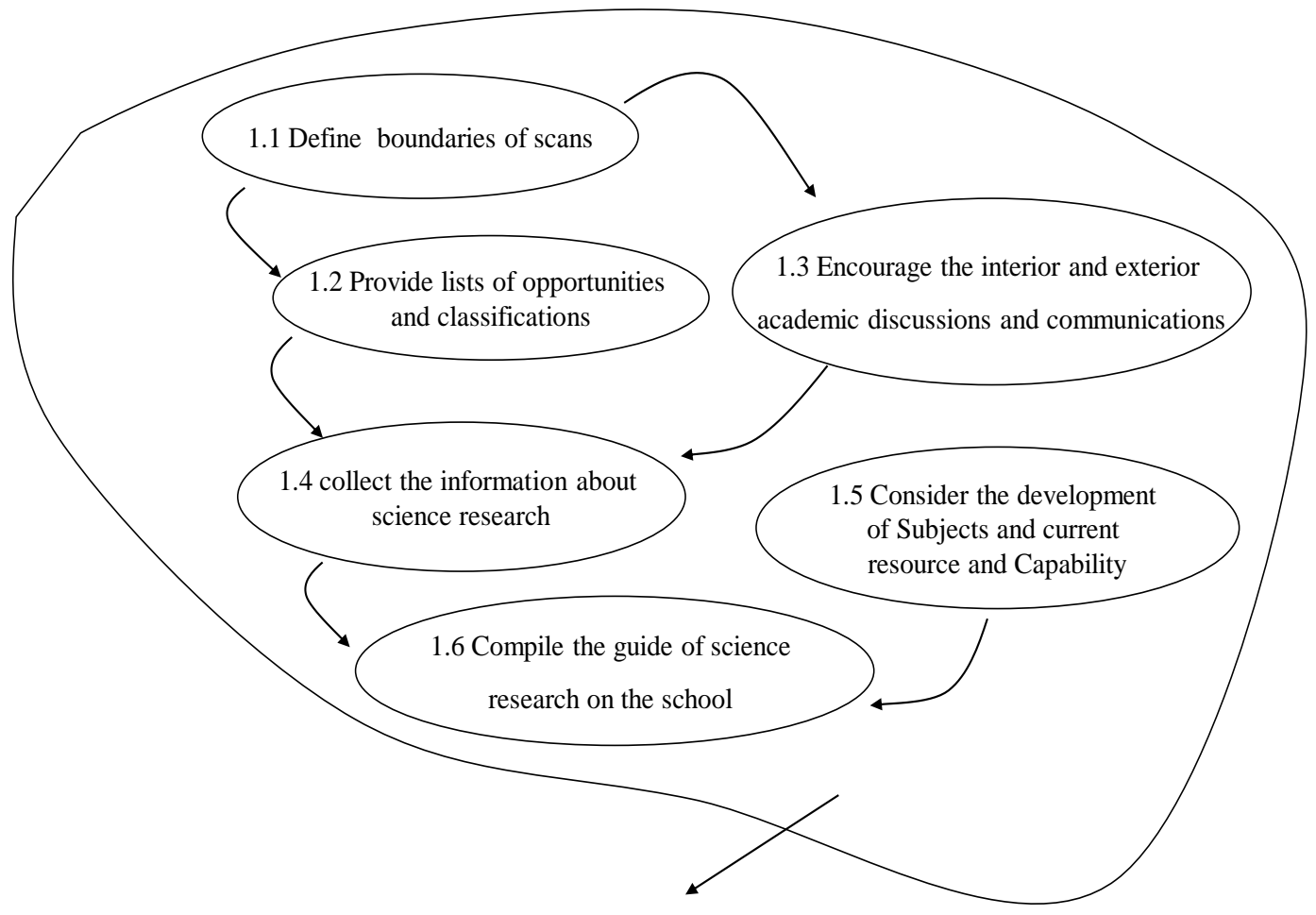

Figure 5: Activity model for "Seek for the research topics with development potential"

It turns out that, in this School, two administrative staff would be assigned to assist the academic staff to identify potential research topics. This was possible since the School aims at research activities of national level and so it is enough for some administrators to browse the relevant research council website or discuss potential needs with its teaching staff. Furthermore, the assigned staff would also compile the collected information and the school guidance into a handbook. Eventually, the sub-activities and a sub-conceptual model were agreed on and these are shown in Figure 5. The stakeholders that are relevant to these activities are shown in Table 3. 
Table 3: Key activities, upper level initial stakeholders and initial stakeholders for Activity 1 "Search for research topics..."

\begin{tabular}{|c|c|c|c|}
\hline $\begin{array}{l}\text { Upper level initial } \\
\text { stakeholders }\end{array}$ & & Key activities & Initial Stakeholders \\
\hline 1.University $(\mathrm{O})$ & 1.1 & Define boundaries of scans & $\begin{array}{l}\text { Academic committee (A), Functional } \\
\text { department (A), Research staff (A\&C), } \\
\text { External researchers (A\&C\&R),School (O) }\end{array}$ \\
\hline 2.School (A) & 1.2 & $\begin{array}{l}\text { Provide lists of opportunities and } \\
\text { discussions }\end{array}$ & $\begin{array}{l}\text { Research team(A \& C), Functional department } \\
\text { (A), School (O) }\end{array}$ \\
\hline $\begin{array}{l}\text { 3.Research team } \\
(\mathrm{A \& C})\end{array}$ & 1.3 & $\begin{array}{l}\text { Encourage the interior and } \\
\text { exterior academic discussion and } \\
\text { communication }\end{array}$ & $\begin{array}{l}\text { Academic committee }(A), \text { Research staff } \\
(A \& C), \text { External research staff }(A, C, R) \text {, } \\
\text { External researcher, School }(O)\end{array}$ \\
\hline \multirow[t]{3}{*}{$\begin{array}{l}\text { 4.External research } \\
\text { stakeholders } \\
(\mathrm{A \& C})\end{array}$} & 1.4 & $\begin{array}{l}\text { Collect information about } \\
\text { science research }\end{array}$ & $\begin{array}{l}\text { Functional department (A), Research staff (A \& } \\
\text { C), Grant awarding bodies (R), School (O) }\end{array}$ \\
\hline & 1.5 & $\begin{array}{l}\text { Consider the development of } \\
\text { subjects and current resource } \\
\text { and capability }\end{array}$ & $\begin{array}{l}\text { Subject leader }(A \& C) \text {, Research team }(A \& C) \text {, } \\
\text { Academic committee (A), External researchers } \\
(A, C, R), \text { School }(O)\end{array}$ \\
\hline & 1.6 & $\begin{array}{l}\text { Compile the guide of science } \\
\text { research on the School }\end{array}$ & $\begin{array}{l}\text { Functional department }(A) \text { : Research } \\
\text { managerial staff (A\&C), School (O) }\end{array}$ \\
\hline
\end{tabular}

Figure 5 shows six activities concerned with "Search for research topics with development potential" (1.1-1.6). For the activity 1.1: Define the boundaries of scans, it is clear and logical that the School needs to provide topic key words to the assigned staff for searching, and these key words have to be discussed and agreed by the academic staff. However it is still not clear how to achieve the activity 1.2 "Provide a list of opportunities and classifications".

To this end, we provide an example to develop a further level of resolution sub-activities for activity 1.2. The what-how-why statement is: "provide lists of opportunities and classifications of potential research topics in order to select suitable ones for the School at a later date". Then after several discussions within the initial stakeholders, five activities (1.2.1-1.2.5) in Figure 6 were agreed. 
1.2 Provide lists of opportunities and classifications
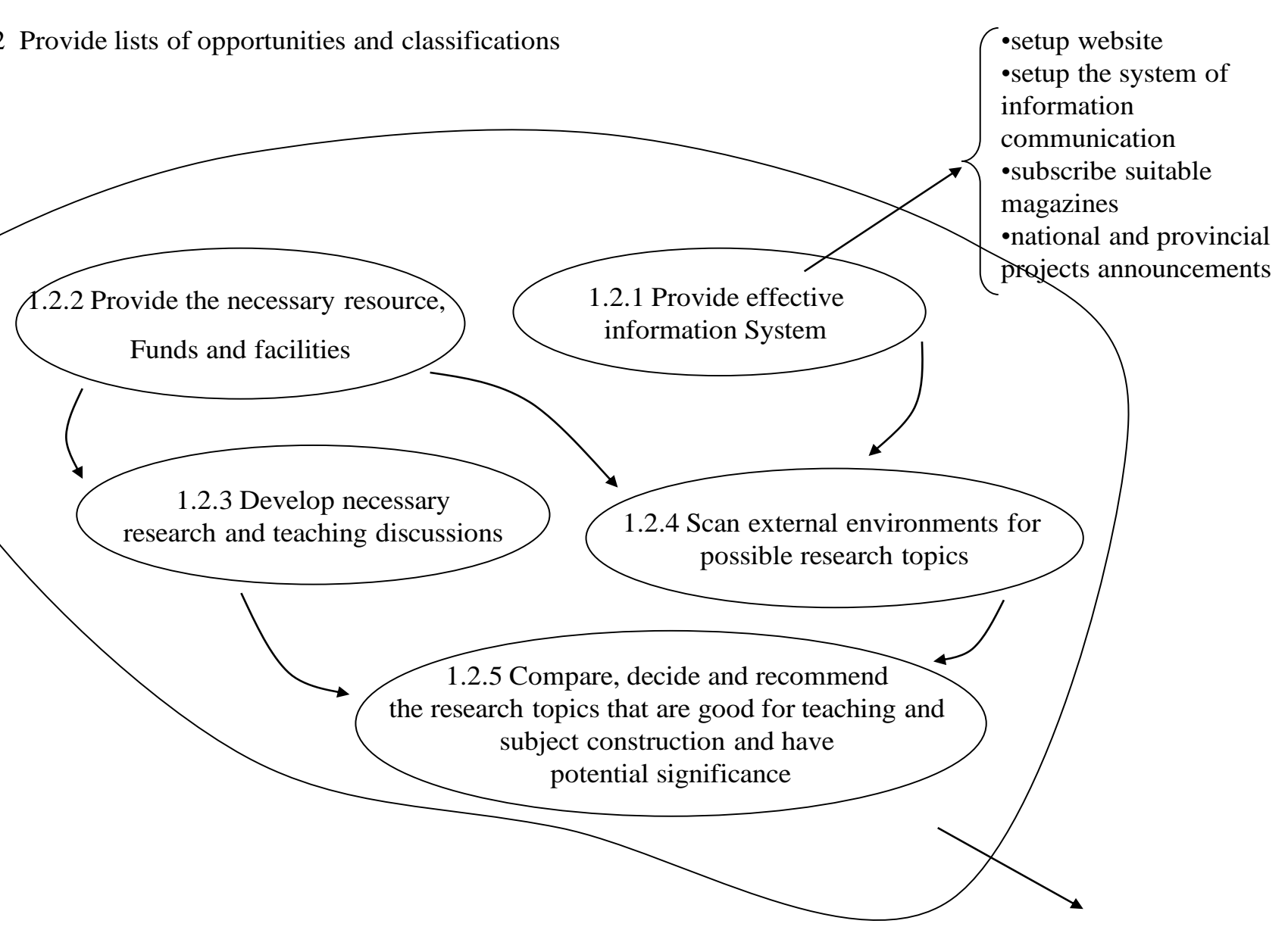

Figure 6: Sub activities for activity 1.2

After this step, some key stakeholders can easily be seen (Table 4). For example, for activities 1.2.1-1.2.5, the following key stakeholders were developed: School research management department, School information management department, academic committee, external research staff, subject leader, academic leader and research team leader and members.

Table 4: Key activities, upper initial stakeholders and key stakeholders for Activity 1.2

"Provide lists of opportunities..." 


\begin{tabular}{|c|c|c|c|}
\hline $\begin{array}{l}\text { Upper level initial } \\
\text { stakeholders }\end{array}$ & & Key activities & key stakeholders \\
\hline $\begin{array}{l}\text { 1. Research team } \\
(\mathrm{A} \& \mathrm{C})\end{array}$ & 1.2 .1 & $\begin{array}{l}\text { Provide the necessary resource, } \\
\text { funds and facilities }\end{array}$ & $\begin{array}{l}\text { Research managerial staff }(\mathrm{A} \& \mathrm{C}) \text {, Grant } \\
\text { awarding body A }(\mathrm{R}) \text {, }\end{array}$ \\
\hline $\begin{array}{l}\text { 2.Function departments } \\
\text { (A) }\end{array}$ & 1.2 .2 & $\begin{array}{l}\text { Provide effective information } \\
\text { system }\end{array}$ & Information supportive staff (A\&C) \\
\hline \multirow[t]{3}{*}{ 3.School (O) } & 1.2 .3 & $\begin{array}{l}\text { Develop necessary research and } \\
\text { teaching discussions }\end{array}$ & $\begin{array}{l}\text { Academic committee(A), External research } \\
\text { staff }(\mathrm{R} \& C), \text { Subject leader }(A \& C), \\
\text { Academic leader (A\&O), Research staff } \\
(A \& C)\end{array}$ \\
\hline & 1.2 .4 & $\begin{array}{l}\text { Scan external environments for } \\
\text { possible research topic }\end{array}$ & $\begin{array}{l}\text { Subject leader (A\&C), Academic leader } \\
(A \& O), \text { Research staff (A\&C), External } \\
\text { research staff (R\&C) }\end{array}$ \\
\hline & 1.2 .5 & $\begin{array}{l}\text { Compare, decide and recommend } \\
\text { the research topic }\end{array}$ & $\begin{array}{l}\text { Academic committee (A), Functional } \\
\text { department (A), Research staff (A\&C), } \\
\text { External research staff (R\&C) }\end{array}$ \\
\hline
\end{tabular}

Step 5: Through the same approach, we can break down all key activities level by level, until the School believes that the processes of achieving all key activities are clear enough and we are able to identify all stakeholders related to bottom level key activities. Theoretically, it is not possible to list all the wider and key stakeholders for the objective of "scientific research" for the School, we can only list all the key stakeholders selected ones from the bottom level of key activities. However, this might be too extensive and specific, especially for top level management. Different levels of management may have different purposes and emphasis when they consider how to manage those key stakeholder groups: for example, top management usually pay more attention to external stakeholders (such as partners and investors), but at the operational level, managers focus more on production and employees.

Thus, we need to consider the existing management hierarchy structure of the School in order to identify key stakeholders related to each key activity from different management levels in the School. The existing management hierarchy structure of the School could be divided into three main categories: 1. University level (which includes academic committee, Foreign Language School and external institutes); 2. School level (which includes scientific research, teaching and functional departments within the School); 3.Departmental level (teams, team leader and members in the departments). According to the existing management structure in the School, starting 
from bottom level key activities, we could summarize a lower level of key stakeholders into upper levels.

For instance the key stakeholders for sub-key activities 1.2.x (which are shown in Table 4) include: School research management department, School information management department, academic committee, external research staff, subject leader, academic leader and research team leader and members. Most of the key stakeholders for the key activities 1.2.x belong to the "departmental level", and then we can summarize them into the upper level of the management structure "the School level", and conclude that the key stakeholders for upper level key activity 1.2 include: School functional department, University functional department, academic committee, research team and external research institutes. Similarly, we could further conclude the key stakeholders for key activities 1.x into the top level of the management structure "University level". The key stakeholders for key activity 1 are: University of Hunan, Foreign Language School, academic committee and external institutes.

To incorporate key stakeholders from bottom to top, we can not only have the key stakeholders who relate to key actions in different levels of the organisation; more important is to incorporate them into the organisation's existing management hierarchy structure. The functions and structures of entire key stakeholder groups in the Foreign Language School of Hunan University are shown in Table 5. This is the key step in our stakeholder identification method. 
Table 5: The functions and structure of key stakeholders

\begin{tabular}{|c|c|c|c|}
\hline \multirow[t]{6}{*}{ School: } & $\begin{array}{l}\text { Administratio } \\
\mathrm{n}\end{array}$ & School leaders & - Relevant activities in conceptual model \\
\hline & & Subject leaders & $\begin{array}{l}-1 ; 1.1 ; 1.2 .4 ; 1.3 .4 ; 1.5 ; 1.5 .4 ; 1.5 .5 ; 1.5 .6 ; 2 ; 2.1 ; 2.5 ; \\
3 ; 3.1 ; 3.2 ; 3.3 ; 3.4 ; 3.5 ; 3.6 ; 3.7 ; 4 ; 4.2 ; 4.4 ; 5 ; 5.3 ; 5.3 .1 ; \\
5.4 ; 8 ; 8.1 ; 8.2 ; 8.3 ; 8.4 .\end{array}$ \\
\hline & \multirow[t]{3}{*}{$\begin{array}{l}\text { Functional } \\
\text { department }\end{array}$} & $\begin{array}{l}\text { Research } \\
\text { managerial staff }\end{array}$ & $\begin{array}{l}\text { 1.1.3; } 1.1 .3 .4 ; 1.3 .4 ; 1.2 .1 ; 1.2 .5 ; 1.2 .3 .1 ; 1.2 .3 .3 ; 1.2 .3 .4 ; 1.4 ; \\
1.5 .1 ; 1.5 .2 ; 1.5 .6 ; 1.6 ; 2.1 ; 2.2 ; 2.3 ; 2.4 ; 2.6 ; 3.8 ; 4.2 ; 5.6 ; \\
\text { 7.3.1; 7.3.2; 7.3.4; 7.3.5; 7.3.6. }\end{array}$ \\
\hline & & $\begin{array}{l}\text { Information } \\
\text { supportive staff }\end{array}$ & - $1.1 .1 ; 1.2 .2 ; 1.4 ; 1.5 .1 ; 1.5 .2 ; 2.1 ; 2.3 ; 2.4 ; 8.4 .6$ \\
\hline & & $\begin{array}{l}\text { equipment } \\
\text { maintenance } \\
\text { staff }\end{array}$ & - $\quad 1.2 .3 .2 ; 3.2 ; 5.3 .4$ \\
\hline & $\begin{array}{l}\text { Academic } \\
\text { committee }\end{array}$ & $\begin{array}{lll}- & 1.1 .5 ; 1.2 .5 \\
8.5 ; & 10.2 ; 10.2 .\end{array}$ & $\begin{array}{l}; 1.5 ; 1.5 .2 ; 1.5 .3 ; 1.5 .5 ; 2.3 ; 2.5 ; 4.2 ; 4.3 ; 4.4 ; 4.5 ; 4.6 ; 4.7 ; \\
; 10.2 .2 ; 10.2 .3\end{array}$ \\
\hline \multirow[t]{4}{*}{$\begin{array}{l}\text { Academic } \\
\text { leader }\end{array}$} & \multicolumn{3}{|c|}{$\begin{array}{l}\text { - } 1.2 .3 ; 1.2 .4 ; 1.5 .4 ; 2.1 ; 2.5 ; 7.1 ; 7.2 ; 7.3 ; 7.5 ; 7.6 ; 8.1 ; 8.2 ; 8.3 ; 8.4 .2 ; 8.4 .3 ; 8.5 ; 10.2 ; \\
10.2 .1 ; 10.2 .2 ; 10.2 .3\end{array}$} \\
\hline & Academic team & \multicolumn{2}{|l|}{ - 7.2} \\
\hline & Team leader & \multicolumn{2}{|c|}{$\begin{array}{ll}\text { - } 7.3 ; 7.3 .1 ; 7.3 .2 ; 7.3 .3 ; 7.3 .4 ; 7.3 .5 ; 7.3 .6 ; 7.3 .7 ; 7.5 ; 7.6 ; 8.2 ; 8.3 ; \\
\text { 8.4; 8.4.1; 8.4.3; 8.4.5. }\end{array}$} \\
\hline & Team member & \multicolumn{2}{|c|}{ - $7.5 ; 7.6 ; 8.4 ; 8.4 .2 ; 8.4 .3 ; 8.4 .4$} \\
\hline \multirow{10}{*}{$\begin{array}{l}\text { Research } \\
\text { team }\end{array}$} & \multicolumn{3}{|c|}{ - $1.2 ; 4 ; 5 ; 6 ; 7 ; 8 ; 9 ; 10$} \\
\hline & $\begin{array}{l}\text { Research team } \\
\text { leader }\end{array}$ & \multicolumn{2}{|c|}{$\begin{array}{ll}-4.1 ; 4.2 ; 4.6 ; 4.7 ; 5.1 ; 5.2 ; 5.3 ; 5.3 .1 ; 5.3 .2 ; 5.3 .3 ; 5.3 .4 ; 5.4 ; 5.5 ; \\
7.3 ; 8.4 .1 ; 9.2 .\end{array}$} \\
\hline & $\begin{array}{l}\text { Research team } \\
\text { member }\end{array}$ & \multicolumn{2}{|c|}{ - $\quad 5.1 ; 5.2 ; 5.3 .3 ; 5.3 .4 ; 5.4 ; 6.1$} \\
\hline & $\begin{array}{l}\text { Research } \\
\text { project leader }\end{array}$ & \multicolumn{2}{|c|}{ 1.5.2; 1.5.3; 1.5.5; 1.5.6; 6.1; 6.2; 6.8; 8.4.1. } \\
\hline & \multirow[t]{3}{*}{ Project team } & \multicolumn{2}{|c|}{ - $6.1 ; 6.2 ; 6.8 ; 9.4 ; 9.5 ; 10.2 .5$} \\
\hline & & Project team leader & \begin{tabular}{l|lll}
$\operatorname{der}$ & $6.3 ; 6.4 ; 6.5 ; 6.6 ; 6.7 ; 6.8 ; 7.3 ; 8.4 .1 ; 9.1 ; 9.2 ;$ \\
& $9.3 ; 9.5 ; 9.7 ; 10.3$.
\end{tabular} \\
\hline & & $\begin{array}{l}\text { Project team } \\
\text { member }\end{array}$ & - $6.3 ; 6.4 ; 6.7 ; 6.8 ; 9.1 ; 9.3 ; 9.5 ; 10.3$ \\
\hline & Research staff & \multicolumn{2}{|c|}{$\begin{array}{l}1.3 ; 1.3 .3 ; 1.3 .4 ; 1.3 .5 ; 1.4 ; 1.5 ; 1.5 .1 ; 1.5 .4 ; 1.5 .5 ; 1.5 .6 ; 2.1 ; 3 ; 7 ; 7.2 ; \\
7.3 ; 9 ; 10 ; 10.1 ; 10.2 .4\end{array}$} \\
\hline & Teaching staff & \multicolumn{2}{|l|}{ - $\quad 3.3 ; 9.6$} \\
\hline & Student & \multicolumn{2}{|c|}{ - $\quad 1.3 ; 1.3 .4 ; 3.4 ; 9.6 ; 10.1$} \\
\hline \multirow[t]{3}{*}{ University } & \multicolumn{3}{|c|}{ - 1.1.3.2; 1.3.2; 3; 3.6; 5; 5.4; 5.6; 9; 9.6; 10.2.4; 10.2.5 } \\
\hline & \multicolumn{3}{|c|}{\begin{tabular}{l|l} 
University research department & $\bullet 4.1 ; 6.8$ \\
\end{tabular}} \\
\hline & \multicolumn{3}{|c|}{ 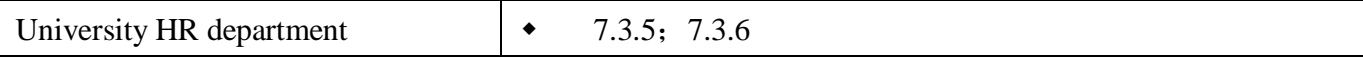 } \\
\hline
\end{tabular}




\begin{tabular}{|l|l|l|}
\hline \multirow{2}{*}{$\begin{array}{l}\text { External } \\
\text { research }\end{array}$} & External resource owner & $-1.3 .4 ; 5$. \\
\cline { 2 - 3 } stakeholder & External research project partner & $-1.1 ; 5.4 ; 5.6 ; 6.8$. \\
\cline { 2 - 3 } & External research staff & $-1.1 .3 ; 1.1 .3 .4 ; 1.2 .3 .4 ; 1.3 ; 1.3 .4 ; 1.5 ; 1.5 .4 ; 5.4 ; 5.6 ;$ \\
& $8 ; 10$ & $-5.4 ; 5.6 ; 8.4 .3 ; 8.4 .4$. \\
\cline { 2 - 3 } & External research partner & $-1.5 ; 1.5 .2 ; 1.5 .3 ; 2.3 ; 8.5 ; 10.2 .1 ; 10.2 .2 ; 10.2 .3$ \\
\cline { 2 - 3 } & External experts & $-4.2 ; 4.6 ; 4.7$. \\
\cline { 2 - 3 } & External project examiner & \\
\hline
\end{tabular}

The reasons to summarize key the stakeholders into the existing management hierarchy structure are: firstly, managers want the stakeholders to have a hierarchy structure. Managers need to consider stakeholder management from different points of view and levels. For instance, top managers will be more likely to consider how to coordinate among key stakeholder groups, to balance their interests and to align their objectives with the organisation's objectives. The departmental managers might consider more how to organize and supervise their staff to achieve the work tasks that are set by the organisation, rather than consider coordinating with other departments. Secondly, managers hope that the key stakeholder groups are broadly in line with the organisation's existing management hierarchy structure, which allows the key stakeholders to facilitate organisation and management: this greatly reduces change to the existing business processes and improves the operability of the key stakeholder management.

After decomposing strategies by using our method, the management of the Foreign Language School had a better understanding of the expectations, roles and responsibilities of the key stakeholders (both internal actors and external wider ones). Accordingly, the management of the school decided to set up a new key performance indicators system to help the implementation of the strategies. One of the key actions in setting up the system is to discuss it thoroughly level by level with the stakeholder groups that have been identified to balance their interests. As suggested by the management, and totally agreed by us, this is important as otherwise these indicators will only sit on paper due to lack of motivation and action enforcement in a public school. According to the feedback of the management teams of the school, management efficiency and staff satisfaction have been improved significantly.

\section{Conclusion}

This paper aims to propose a stakeholders identification method that can be applied to all organisations The method begins from an understanding of the management situation and objectives then uses SSM as to break down the activities to 
whatever level of detail is considered necessary in order to identify both wider and key stakeholders at all levels of the organisations activities. From this, a comprehensive list of stakeholders can be established which provides the basis for key stakeholder management. Stakeholder theory and methodology should ultimately serve the organisation's management.

The stakeholder identification and analysis method defined in this paper also improves existing stakeholder theory in the following two aspects. Firstly, this method provides a methodological support for distinguishing the importance of the different stakeholders. This method connects the various stakeholders into the implementation process of the organisation's objectives and key activities, which allows managers to distinguish more clearly the relative importance between the stakeholder groups.

Secondly, our method can provide the foundation for the balancing and coordination of the key stakeholders' interests. From the methodology interpretation and the Foreign Language School case study, it is critical to understand that balancing or coordinating the key stakeholders' interests will influence and be influenced by the organisation's existing management hierarchy and structure. The organisation's business processes or management structures can be changed or restructured when the existing processes or management are difficult to adapt to the interests of key stakeholders. In order to balance and coordinate the key stakeholders' interests especially in the case of the absence of the dominant stakeholder (e.g. the owner in a private company), and with multiple objectives (e.g. social values and economic values) in the public organisation - this method starts from the organisation's strategic objectives and, depending on the organisational level and specific management scenarios, identifies both wider and key stakeholder groups based on the critical path (key activities ).

Slightly different variants of the above methodology have now been used in our projects on performance management and strategy management, particularly for the public sector, although they are not as formal as is described in this paper. For example, in a recent project on setting up a performance measurement system for a Chinese public hospital, it was found to be very important to identify all the stakeholders relevant to management and to balance their interests while deploying its new strategies and developing measurements. Otherwise, the staff involved may only be interested in those things that are in their personal interest or will increase their rewards directly. 


\subsection{Limitations}

We should mention a number of limitations of the method and the empirical base. Some of the limitations apply to stakeholder analysis methods generally, For example, there may be time constraints. Our stakeholder identification and analysis method emphasizes involvement and discussion among the various stakeholder groups, during the key activities decision making process. However, managers often need to make quick decisions and deal with many unexpected urgent circumstances. Holding the discussion and debate may not be realistic during time-constrained situations.

Second, there are always some conflicting interests among the stakeholder groups. Managers need to balance their needs and make decisions. Some groups, particularly marginalized groups, may easily have their interests ignored during the balancing process. Some of the other methods discussed in this paper, e.g., the participative techniques of Bryson, may well be useful in engendering useful debates between the groups involved.

Third, the stakeholder identification method is related to the given time period and key objectives and activities, and the interests of stakeholder groups could change as well. Therefore, the stakeholder identification and analysis needs to keep being updated and, again, this will cost time and resources. Nevertheless, the importance of stakeholders makes it worthwhile doing.

We also have to mention the underpinning use of SSM. This is a very well-known methodology but does carry with it concepts and assumptions that are sometimes difficult to enact with ordinary managers and participants. It was for this reason that the method used actually simplifies SSM and talks about "what, why and how" rather than root definitions and conceptual models. Also, our use of SSM is very much "primary task" rather than "issue based". It expects that it will be relatively easy to identify and agree on the basic mission or strategy of the organisation, and then concentrates on deconstructing this into lower-level activities, measures of performance and stakeholders. This may generally be the case with clearly defined public sector organisations such as universities or hospitals. If, in a particular situation, it became apparent at the outset that there was in fact significant disagreement about the strategic direction of the organisation then a fuller and more issue-based version of SSM could be used at the outset. 


\section{References}

Ackermann, F. (2012). Problem structuring methods 'in the dock': Arguing the case for soft OR. European Journal of Operational Research, 219(3), 652-658.

Ackoff, R. L. (1974). The social responsibility of operational research. Operational Research Quarterly, (25), 361-371.

Ackermann, F., \& Eden, C. (2011). Strategic management of stakeholders: Theory and practice. Long Range Planning, 44(3), p. 179-196.

Alkhafaji, A. F. (1989). A stakeholder approach to corporate governance: Managing in a dynamic environment. New York: Quorum Books.

Ansoff, H. I. (1965). Corporate strategy: Business policy for growth and expansion McGraw-Hill Book.

Berman, S. L., Wicks, A. C., Kotha, S., \& Jones, T. M. (1999). Does stakeholder orientation matter? the relationship between stakeholder management models and firm financial performance. Academy of Management Journal, 42(5), 488-506.

Bowen, H. R. (1953). Social responsibilities of the businessman New York: Harper \& Row.

Bowie, N. (1988). The moral obligations of multinational corporations. in S. luper-foy (ed.), problems of international justice: 97-113. Boulder, CO: Westview Press.

Bryson, J. (2004). What to do when stakeholders matter, Public Management Review, 6:1, p. 21-53.

Checkland, P. B. (1972). Towards a systems-based methodology for real-world problem solving. Journal of Systems Engineering, 3(2), 87-116.

Checkland, P., \& Poulter, J. (2006). Learning for action: A short definitive account of soft systems methodology and its use for practitioner, teachers, and students Wiley Chichester.

Churchman, C. W. (1968). The systems approach. New York: Delta.

Churchman, C. W. (1971). The design of inquiring systems. New York: Basic Books,.

Clarkson, M. (1994). A risk based model of stakeholder theory. Proceedings of the Second Toronto Conference on Stakeholder Theory, 18-19.

Clarkson, M. (1995). A stakeholder framework for analyzing and evaluating corporate social performance. Academy of Management Review, 92-117.

Crane, A., \& Ruebottom, T. (2011). Stakeholder theory and social identity: Rethinking stakeholder identification. Journal of Business Ethics, 102(1), 77-87.

De Brucker, K., Macharis, C., \& Verbeke, A. (2013). Multi-criteria analysis and the resolution of sustainable development dilemmas: A stakeholder management approach. European Journal of Operational Research, 224(1), 122-131. 
Donaldson, T., \& Preston, L. E. (1995). The stakeholder theory of the corporation:

Concepts, evidence, and implications. Academy of Management Review, 20(1), 65-91.

Eden, C., \& Ackermann, F. (1998). Strategy making: The journey of strategic management. London: Sage.

Ehreth, J. L. (1988). A competitive constituency model of organisational effectiveness and its application in the health industry. Paper Presented at the Academy of Management Annual Meeting, Anaheim, CA.

Enserink, B., Hermans, L., Kwakkel, J., Thissen, W., Koppenjan, J., \& Bots, P. (2010). Policy analysis of multi-actor systems, The Hague: Lemma.

Freeman, R. E. (1984a). Strategic management: A stakeholder approach. Boston: Pitman.

Freeman, R. E. (1999). Divergent stakeholder theory. Academy of Management Review, 24(2), 233-236.

Freeman, R. E., Harrison, J. S., Wicks, A. C., Parmar, B. L., \& De Colle, S. (2010). Stakeholder theory: The state of the art. Cambridge: Cambridge University Press.

Freeman, R. E., \& Reed, D. L. (1983). Stockholders and stakeholders: A new perspective on corporate governance. California Management Review, 25(3), 93-94.

Freeman, R. E. (1984b). Strategic management: A stakeholder approach. Boston: Pitman. Friedman, A. L., \& Miles, S. (2002). Developing stakeholder theory. Journal of Management Studies, 39(1), 1-21.

Goodpaster, K. E. (1991). Business ethics and stakeholder analysis. Business Ethics Quarterly, 53-73.

Harrison, J. S., Bosse, D. A., \& Phillips, R. A. (2010). Managing for stakeholders, stakeholder utility functions, and competitive advantage. Strategic Management Journal, 31(1), 58-74.

Hermans, L. M., \& Thissen, W. A. (2009). Actor analysis methods and their use for public policy analysts. European Journal of Operational Research, 196(2), 808-818.

Hill, C. W. L., \& Jones, T. M. (1992). Stakeholder - agency theory. Journal of Management Studies, 29(2), 131-154.

Jensen, M. C., \& Meckling, W. H. (1976). Theory of the firm: Managerial behavior, agency costs and ownership structure. Journal of Financial Economics, 3(4), 305-360. Johnson, G., \& Scholes, K. (2002). Exploring corporate strategy. Harlow: Prentice-Hall. Jones, T. M. (1980). Corporate social responsibility revisited, redefined. California Management Review, 22(3), 59-67.

Jones, T. M. (1995). Instrumental stakeholder theory: A synthesis of ethics and economics. Academy of Management Review, 20(2), 404-437. 
Kodikara, P. N., Perera, B., \& Kularathna, M. (2010). Stakeholder preference elicitation and modelling in multi-criteria decision analysis-A case study on urban water supply. European Journal of Operational Research, 206(1), 209-220.

Liu, W. B., Meng, W., Mingers, J., Tang, N., \& Wang, W. (2012). Developing a performance management system using soft systems methodology: A chinese case study. European Journal of Operational Research, 223(2), 529-540.

Meyer, J. W., \& Rowan, B. (1977). Institutionalized organisations: Formal structure as myth and ceremony. American Journal of Sociology, 83(2), 340-363.

Midgley, G. (2000). Systemic intervention: Philosophy, methodology and practice. New York: Kluwer Academic.

Mingers, J. (2011a). Ethics and OR: Operationalising discourse ethics. European Journal of Operational Research, 210(1), 114-124.

Mingers, J. (2011b). Soft OR comes of age—but not everywhere! Omega, 39(6), 729-741.

Mingers, J., Liu, W., \& Meng, W. (2009). Using SSM to structure the identification of inputs and outputs in DEA. Journal of the Operational Research Society, 60(2), 168-179.

Mingers, J., \& Rosenhead, J. (2004). Problem structuring methods in action. European Journal of Operational Research, 152(3), 530-554.

Mitchell, R. K., Agle, B. R., \& Wood, D. J. (1997). Toward a theory of stakeholder identification and salience: Defining the principle of who and what really counts. Academy of Management Review, 853-886.

Mitroff, I. I. (1983). Stakeholders of the organizational mind. San Francisco: Jossey-Bass.

Munda, G. (2004). Social multi-criteria evaluation: Methodological foundations and operational consequences. European Journal of Operational Research, 158(3), 662-677.

Näsi, J. (1995). What is stakeholder thinking? A snapshot of a social theory of the firm. in J. näsi (ed.), understanding stakeholder thinking: 19-32. LRS-Julkaisut Oy.

Pfeffer, J. (1981). Power in organisations. Marshfield, MA: Pitman.

Pouloudi, A. (1999). Aspects of the stakeholder concept and their implications for information systems development. In Proceedings of the 32nd Hawaii International Conference on System Science, 1-17.

Pouloudi, A., \& Whitley, E. A. (1997). Stakeholder identification in inter-organisational systems: Gaining insights for drug use management systems. European Journal of Information Systems, 6(1), 1-14.

Rodgers, W., \& Gago, S. (2004). Stakeholder influence on corporate strategies over time. Journal of Business Ethics, 52(4), 349-363. 
Salancik, G. R., \& Pfeffer, J. (1978). A social information processing approach to job attitudes and task design. Administrative Science Quarterly, 224-253.

Sharma, S., \& Henriques, I. (2005). Stakeholder influences on sustainability practices in the canadian forest products industry. Strategic Management Journal, 26(2), 159-180.

Simmons, J. (2003). Reconciling effectiveness and equity in performance management: A stakeholder synthesis approach to organisational systems design. Systemic Practice and Action Research, 16(5), 355-365.

Simmons, J., Iles, P., \& Yolles, M. (2005). Identifying those on board 'the moving train': Towards a stakeholder - focused methodology for organisational decision making. Systems Research and Behavioral Science, 22(1), 41-53.

Suchman, M. C. (1995). Managing legitimacy: Strategic and institutional approaches. Academy of Management Review, 20(3), 571-610.

Thompson, J. K., Wartick, S. L., \& Smith, H. L. (1991). Integrating corporate social performance and stakeholder management: Implications for a research agenda in small business. Research in Corporate Social Performance and Policy, 12, 207-230.

Trutnevyte, E., Stauffacher, M., \& Scholz, R. W. (2012). Linking stakeholder visions with resource allocation scenarios and multi-criteria assessment. European Journal of Operational Research, 219(3), 762-772.

Ulrich, W. (1983). Critical heuristics of social planning: A new approach to practical philosophy. Bern: Haupt.

Vidgen, R. (1997). Stakeholders, soft systems and technology: Separation and mediation in the analysis of information system requirements. Information Systems Journal, 7(1), 21-46.

Vos, J. F. (2003). Corporate social responsibility and the identification of stakeholders. Corporate Social Responsibility and Environmental Management, 10(3), 141-152.

Wang, J., Ge, J., \& Lu, Q. (2012). A review of stakeholder analysis. In System Science, Engineering Design and Manufacturing Informatization ICSEM 2012 3rd

International Conference on Systems Engineering and Modelling, p. 40-43. IEEE.

Williamson, O. E. (1975). Markets and hierarchies. New York: Free Press.

Williamson, O. E. (1985). The economic intstitutions of capitalism. New York: Free Press. 